\title{
The individual's perception of institutional environments and entrepreneurial motivation in developing economies: Evidence from Cape Verde
}

\begin{tabular}{|c|c|}
\hline $\begin{array}{l}\text { Authors: } \\
\text { Antonia M. Ga } \\
\text { Maria G. Garc } \\
\text { Jeremias Dias }\end{array}$ & $\begin{array}{l}\text { arcia-Cabrera }^{1} \\
\text { ia-Soto }^{1} \\
\text {-Furtado }^{2}\end{array}$ \\
\hline $\begin{array}{l}\text { Affiliations: } \\
{ }^{1} \text { Department }\end{array}$ & of Business \\
\hline $\begin{array}{l}\text { Administratio } \\
\text { de Economía, } \\
\text { y Turismo, Un } \\
\text { Las Palmas de } \\
\text { Spain }\end{array}$ & $\begin{array}{l}\text { n, Facultad } \\
\text { Empresa } \\
\text { iversidad de } \\
\text { Gran Canaria, }\end{array}$ \\
\hline $\begin{array}{l}{ }^{2} \text { Economic Co } \\
\text { West African } \\
\text { (ECOWAS), Ca }\end{array}$ & $\begin{array}{l}\text { mmunity of } \\
\text { States } \\
\text { pe Verde }\end{array}$ \\
\hline $\begin{array}{l}\text { Correspondin } \\
\text { Antonia Garci } \\
\text { antonia.garcia }\end{array}$ & $\begin{array}{l}\text { g author: } \\
\text { a-Cabrera, } \\
\text { @ulpgc.es }\end{array}$ \\
\hline $\begin{array}{l}\text { Dates: } \\
\text { Received: } 17 \text { I } \\
\text { Accepted: } 13 \\
\text { Published: } 10\end{array}$ & $\begin{array}{l}\text { Mar. } 2018 \\
\text { June } 2018 \\
\text { Sept. } 2018\end{array}$ \\
\hline $\begin{array}{l}\text { How to cite th } \\
\text { Garcia-Cabrer } \\
\text { Garcia-Soto, } \\
\text { Dias-Furtado, } \\
\text { individual's pe } \\
\text { institutional e } \\
\text { and entreprer } \\
\text { motivation in } \\
\text { economies: E } \\
\text { Cape Verde', S } \\
\text { Journal of Eco } \\
\text { Management } \\
\text { a2377. https:/ } \\
\text { 10.4102/sajer }\end{array}$ & $\begin{array}{l}\text { his article: } \\
\text { a, A.M., } \\
\text { M.G. \& } \\
\text { J., 2018, 'The } \\
\text { erception of } \\
\text { nvironments } \\
\text { heurial } \\
\text { developing } \\
\text { vidence from } \\
\text { South African } \\
\text { nomic and } \\
\text { Sciences 21(1), } \\
\text { //doi.org/ } \\
\text { ns.v21i1.2377 }\end{array}$ \\
\hline $\begin{array}{l}\text { Copyright: } \\
\text { ( ) 2018. The } \\
\text { Licensee: AOS } \\
\text { is licensed un } \\
\text { Creative Com } \\
\text { Attribution Lic }\end{array}$ & $\begin{array}{l}\text { Authors. } \\
\text { IS. This work } \\
\text { der the } \\
\text { mons } \\
\text { cense. }\end{array}$ \\
\hline Read online: & \\
\hline 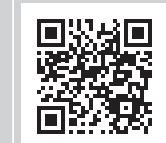 & $\begin{array}{l}\text { Scan this QR } \\
\text { code with your } \\
\text { smart phone or } \\
\text { mobile device } \\
\text { to read online. }\end{array}$ \\
\hline
\end{tabular}

Authors:

Maria G. Garcia-Soto ${ }^{1}$ (D)

Jeremias Dias-Furtado ${ }^{2}$

Affiliations:

Department of Business y Turismo, Universidad de Las Palmas de Gran Canaria,

West African States

Corresponding author: Antonia Garcia-Cabrera,

Dates:

Accepted: 13 June 2018

How to cite this article: Garcia-Cabrera, A.M.

Garcia-Soto, M.G. \&

Dias-Furtado, J., 2018, institutional environments and entrepreneurial Journal of Ecor Management Sciences 21(1) a2377. https://doi.org/

Copyright: Licensee: AOSIS. This work

is licensed under the Creative Commons Attribution License.
Background: International organisations and national governments have made great efforts to stimulate entrepreneurial activity in the less-advanced economies, but the results of their programmes have often been disappointing. This may be because a distinction between the institutional factors that generate an individual's desire to become an entrepreneur and those that generate a motivation that actually leads to entrepreneurial action has not been considered sufficiently.

Aim: This work is an attempt to respond to the following question on the basis of the individual's perception of regulative, normative and cognitive institutions: In developing economies, what institutional factors generate an entrepreneurial motivation that makes individuals desire to become entrepreneurs and what factors cause an entrepreneurial motivation that actually leads them to entrepreneurial action?

Setting: We use empirical evidence from the African nation of Cape Verde for the analysis. The study was carried out on 6 of the 10 islands of the archipelago.

Method: The sample of study comprises 237 people: 93 entrepreneurs and 144 individuals with different levels of desire to become an entrepreneur. We used multiple linear regression analysis to test the hypotheses.

Results: Our findings show that institutional factors which generate the entrepreneurial motivation that forges an individual's desire to become an entrepreneur, and those which generate the motivation that leads him or her to actually set up his or her own business are not the same. We also find differences in the institutional factors that influence the opportunity, necessity and social components of entrepreneurial motivation.

Conclusion: Theoretical implications for better understanding the factors that condition entrepreneurship in developing economies and practical implications useful for improving the planning of growth in these countries are offered.

\section{Introduction}

International organisations and national governments have made great efforts to stimulate entrepreneurial activity in the less-advanced economies. To this end, they have paid much attention to the environmental factors that condition entrepreneurial behaviour (Stenholm, Acs \& Wuebker 2013), but the results of their programmes have often been disappointing (Mahto \& McDowell 2018) - for example, regulation to foster entrepreneurial activity such as incentives to push individuals towards entrepreneurship, the offering of financial resources to support the new ventures, education and scientific training, etc. This may be because a distinction between the institutional factors which generate an individual's desire to become an entrepreneur and those which generate a motivation that actually leads to entrepreneurial action has not been considered sufficiently, this being a distinction of particular relevance since human motivations are able to influence entrepreneurial decisions and actual business action (Carsrud \& Brännback 2011; Mahto \& McDowell 2018; Shane, Locke \& Collins 2003). In addition, the programmes implemented have not sufficiently distinguished between the different components of entrepreneurial motivation and their antecedents either. The academic literature has studied two of these components in some depth: opportunity and necessity. These two components can - either individually or in combination - give rise to entrepreneurship (Williams 2009). Distinguishing between them is important because previous research has found that it is entrepreneurship motivated mainly by opportunity that generates economic growth and employment (Acs, Desai \& Hessels 2008). On the other hand, the most recent literature has looked at the social component 
of entrepreneurial motivation and its role in the sustainable development of the less-advanced economies (e.g. Azmat 2013; Ghalwash, Tolba \& Ismail 2017).

Although the previous literature suggests that the contextual factors of the environment condition the development of entrepreneurial motivation (Hechavarria \& Reynolds 2009), researchers have not yet fully established the factors that generate each component of entrepreneurial motivation. For example, the research warns that because of the difficulties developing economies face, entrepreneurship motivated mainly by necessity is relatively common, while entrepreneurship motivated by opportunity is less common (Valliere \& Peterson 2009). However, an entrepreneur can simultaneously develop two or more of these components (Jayawarna, Rouse \& Kitching 2013) and one component may turn into another if the context changes (Williams 2009). Thus, it would be interesting to identify the environmental factors that generate each component of entrepreneurial motivation, because this would help provide guidelines for policymakers seeking to encourage particular motivations. In the current work, we aim to identify which factors in the institutional environment influence the opportunity, necessity and social components of entrepreneurial motivation, distinguishing between those factors that forge an individual's desire to become an entrepreneur and those that actually lead them into entrepreneurial action. We use the recent approaches to new institutional theory for this purpose.

A growing body of literature supports the institutional approach, which argues that the institutions - for example, laws, cultural values, business practices and knowledge govern human interactions and condition the behaviour of people and organisations (North 1990; Puffer, McCarthy \& Boisot 2010). The first versions of new institutionalism stress the individual's compliance with and adaptation to their institutional environment, but subsequent versions - labelled 'neo-institutionalism' by Greenwood and Hinings (1996), who coined the term - afford greater importance to the actor's role and capacity of agency in the decision processes (Battilana, Leca \& Boxenbaum 2009).

Studies based on the first versions of new institutionalism take a macro-perspective and apply a determinist approach to explain how the institutions at the national level, measured via proxies taken from international databases, facilitate or constrain the economic activity of the individual firm. Nevertheless, the latest interpretations note that the individual has the ability to act willingly in responding to the institutional framework (Meyer et al. 2009), so they attempt to establish a bridge between the macro and micro-levels of analysis (Dunning \& Lundan 2008) based on the individual's capacity for agency. According to this approach, individuals adopt a leading role when they interpret their environment and make business decisions (North 1990). Thus, Dunning and Lundan (2008:580) defend a 'bottom up' logic in their study of the relationship between businesses and institutions, arguing that the firm's activity 'rests on the information processing of the individual entrepreneur'.
The literature on entrepreneurship has provided support for this idea, commonly showing interest in identifying, at the micro-level, the entrepreneur's characteristics (e.g. Busenitz, Gomez \& Spencer 2000), cognitions (Kautonen, Gelderen \& Fink 2015) and motivation (e.g. Jayawarna et al. 2013) as antecedents that give rise to entrepreneurial action. However, entrepreneurial motivation is conditioned by the institutional environment (Hechavarria \& Reynolds 2009; Stenholm et al. 2013). Therefore, in focusing on how the individual perceives the institutional framework and, consequently, how their motivations evolve, a causal link may be uncovered which could shed light on the relationships observed by researchers at the macro-level (Szyliowicz \& Galvin 2010). In this respect, it seems important to distinguish between individuals claiming they have a motivation to engage in entrepreneurial action but who have not founded any business (i.e. they are not yet actual entrepreneurs) and those who have actually put their ideas into practice and founded their own business (i.e. they are entrepreneurs). This is because such a distinction would differentiate between the institutions that lead the individual to develop motivations encouraging their desire to be an entrepreneur, from those leading them to actually engage in entrepreneurship. This distinction seems to be crucial if we are to design the right programmes aimed at encouraging entrepreneurship in developing economies, particularly if the research finds important evidence in this respect.

However, except for the work conducted by Urban (2013), which analyses the influence of the individual's perception of institutional environment on students' entrepreneurial intentions in an emerging economy, previous literature on entrepreneurship has never used this approach. Indeed, we have found no previous studies exploring the aforementioned distinction and accepting that the entrepreneur can have diverse motivations (Birley \& Westhead 1994). Thus, in the current research, we study the opportunity, necessity and social components of entrepreneurial motivation to identify the factors of the institutional environment that can influence them, and hence encourage entrepreneurial action in a developing economy. The expected contribution of this work is of relevance because according to Bjørnskov and Foss's (2016) literature review, there is a lack of detailed micro-level data that can help to understand the interaction between macro-level institutions and individual and firm-level responses, which prevent more detailed knowledge about the transmission mechanisms connecting institutions and entrepreneurial outcomes. Our work answers this call, and for this purpose we carried out a study in the Republic of Cape Verde, which is an ideal country for this research because its economy is poor in resources and natural wealth but it has become one of the five most successful countries in Africa at encouraging entrepreneurship. Specifically, we take evidence from a sample of 237 people, 93 of whom actually set up and manage their own business (entrepreneur subsample), and 144 who are individuals with different levels of desire to become an entrepreneur (hereafter, nonentrepreneur subsample). The results of this research may be useful for developing economies since, in identifying the 
institutional factors that generate each component of entrepreneurial motivation, we offer new implications for improving the planning of growth in developing economies. This is very important for these economies because the different components of entrepreneurial motivation do not generate an equal proportion of productive entrepreneurship (Acs et al. 2008; Valliere \& Peterson 2009). For this reason, results may also be relevant for researchers and politicians from developed economies, where providing a boost to productive entrepreneurs is often also a challenge. They might gain awareness through our study about the existence of the various effects of institutional factors on the different components of entrepreneurial motivation, as well as on the individual's final decision to commit to entrepreneurial action; in other words, on the interaction between macro-level institutions and individual-level responses, which is currently not well enough understood (Bjørnskov \& Foss 2016).

The manuscript is organised into six sections. Following this introductory section, we review the literature on institutional environment and entrepreneurial motivation in developing countries; we then develop the research hypotheses. This is followed by an explanation of the research methodology used to carry out the study. In the next section, we present the results with regard to hypothesis testing. The article ends with the discussion and conclusion sections.

\section{Theoretical foundations}

\section{Institutional environment and the individual's institutional perceptions}

Institutions make the rules of the game in an organisational field and determine the viability of participating in an economic activity (North 1990). Under the institutional approach, the type of organisation created will be determined by the opportunities that the institutional framework provides (Meyer \& Nguyen 2005), for example in terms of new firms' focus on innovation and international trade growth (Simón-Moya, Revuelto-Taboada \& FernándezGuerrero 2014). Scott (1995) conceptualised three dimensions of institutions as things that happen within them and because of them: regulative, normative or cognitive. The regulative dimension includes the laws governments introduce to encourage certain behaviours and discourage others (Scott 1995), and their subsequent effect on economic growth (Stenholm et al. 2013). The normative dimension has to do with the cultural values relating to acceptable human behaviour (Scott 1995), among them desirable career choices (Lim, Oh \& De Clercq 2016). The cognitive dimension reflects the business knowledge organisations share in an area and includes the past decisions that other organisations

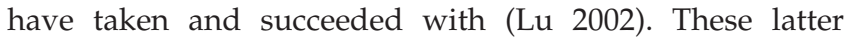
elements contain validated experiences (Scott 1995) that help the decision-maker to choose between acceptable options ( $\mathrm{Lu}$ 2002). Under this institutional approach, entrepreneurship is considered to be a product of the institutional factors (Williams, \& Gurtoo 2017) and, consequently, the three institutional dimensions are currently being widely considered in the study of entrepreneurship (e.g. Lim et al. 2016; Simón-Moya et al. 2014; Stenholm et al. 2013; Valdez \& Richardson 2013).

The most recent versions of new institutionalism posit that individuals take on an active role in the institutional process as they can either comply with the current institutions, adapt to them, ignore them or attempt to modify them if they are obstacles to them achieving their objectives (Battilana et al. 2009). Under this new approach, the regulative, normative and cognitive dimensions are social structures that limit and enable, but do not determine the actor's final choice (Hoffman \& Ventresca 2002), the latter retaining some room for discretion. Reactions, which will cause response heterogeneity, are likely dependent on the individual's level and kind of motivation (Bjørnskov \& Foss 2016), and the relevance granted to the information perceived in the institutional environment (Dunning \& Lundan 2008), among other things. At this point, we should remember that only individuals can possess motives and make decisions to achieve their goals within a particular institutional framework (North 1990). Hence, institutions represent a reality that is objective and external to the individual (North 1990), who will hold their own, subjective point of view regarding that reality (García-Cabrera, García-Soto \& Durán-Herrera 2016; Urban 2013), and so different individuals will interpret and respond to the possibilities offered by the current institutions in different ways (Bjørnskov \& Foss 2016; Szyliowicz \& Galvin 2010; Valdez \& Richardson 2013; Zwan et al. 2016). Thus, the approach offered by the most recent form of institutionalism is useful in the study of entrepreneurship because it provides theoretical bases that allow us to distinguish between the external, objective reality and the individual's subjective perception of that reality, which is what will affect their motivations and actions.

\section{Components of entrepreneurial motivation}

Although research on the concept of entrepreneurial motivation is scarce (Mahto \& McDowell 2018), the term can be understood as those factors or forces within individuals that encourage them to become entrepreneurs (Carsrud \& Brännback 2011; Shane et al. 2003). According to this, Fossen and Büttner (2013:67) observe that 'entrepreneurs are a heterogeneous group, primarily because of large differences in their motivations to become entrepreneurs'. Despite the warnings against an over-simplification of these motivations (Williams 2009) - for example, economic gain, improved social status, contribution to community well-being (Birley \& Westhead 1994; Jayawarna et al. 2013; Manolova, Eunni \& Gyoshev 2008) - authors have frequently classified them: opportunity and necessity (e.g. Block \& Wagner 2010; Zwan et al. 2016). But there has also been recognition that both types of motivation can be components of a single individual's entrepreneurial motivation at one point or another, or even simultaneously at a particular point in time, and even that the main component of a person's entrepreneurial motivation can transform into a different component over time (Williams 2009; Williams \& Gurtoo 2017). The opportunity component 
exists in individuals who voluntarily decide to initiate a business project in order to exploit opportunities that allow them to achieve their personal goals, while the necessity component exists in individuals who fail to find employment or satisfactory employment and see entrepreneurship as a last resort (Williams 2009).

In addition, the recent literature has paid particular attention to the social component of entrepreneurial motivation (Mair \& Martí 2006), especially in developing economies (Azmat 2013; Ghalwash et al. 2017). This component, like the previous two, aspires to create value, but unlike the other two the entrepreneur also has intrinsically social reasons. The social component of motivation leads the individual to explore opportunities that allow them to meet social needs or drive social change - for example, helping others, helping the community, etc. (Ghalwash et al. 2017; Renko 2013). Thus, the social motivation we analyse corresponds to the entrepreneur's ethical and moral responsibility motives, which combine with other, commercial motives to give rise to profitable and sustainable businesses (Renko 2013). In the opportunity component, the entrepreneurship contributes to generating wealth and employment in an area and hence can be considered productive from a social perspective (Acs et al. 2008), but the priority in this component is the pursuit of self-realisation, wealth or personal well-being (Jayawarna et al. 2013).

Conditions encouraging each of the three components have barely been analysed in the literature. Some studies identify individual-level antecedents - for example, business experience, education (Jayawarna et al. 2013) - while others stress that such motivations are associated with environmental factors (Cassar 2007), although the literature has yet to determine the possible influence of the institutions on their development.

\section{The relationship between the institutional environment and entrepreneurial motivation in developing economies}

A developing country is a nation with a less-developed industrial base and a lower Human Development Index than other countries (Sullivan \& Sheffring 2003). The contexts of developing countries significantly contrast with those of developed countries, as the former deal with challenges such as extensive poverty and poor transportation and financial infrastructure (Ghalwash et al. 2017). In addition, such countries commonly lack institutional structures that stimulate entrepreneurial activity (Meyer et al. 2009), their legislation tends to be unstable and at the mercy of unpredictable and inconsistent changes (Puffer et al. 2010), and there is limited information about the competition in the market (Acs et al. 2008) and insufficient knowledge about how to exploit business opportunities. Other institutional limitations are bureaucracy (Ghalwash et al. 2017), the ineffective functioning of the public administrations, the lack of independence of the legal system, and political instability (Puffer et al. 2010). As a consequence, the high level of uncertainty limits the number of business opportunities because entrepreneurial activity becomes more complex and riskier (Manolova et al. 2008). In addition, in developing country contexts, illiteracy and low levels of education are frequent (Ghalwash et al. 2017), so the education system is hardly able to generate a knowledge base that can lead individuals to entrepreneurship (Urban 2013). Other institutional factors, such as cultural and social norms, do not usually make entrepreneurship a highly desirable career choice for the country's population (Herrington, Kew \& Kew 2010).

Thus, the abovementioned regulative, normative and cognitive institutions in developing countries may lower entrepreneurial motivation in the area (Hechavarria \& Reynolds 2009; Urban 2013). That is relevant because, as stated by Shane et al. (2003), human motivations influence decisions made by individuals after the discovery of business opportunities, so that the variance in entrepreneurial motivations across people will affect whoever exploits identified opportunities by starting up a firm, decides to stick to the process, or perhaps fails to find the suitable setting needed to turn desires into actions. In this respect, Carsrud and Brännback (2011) state that motivations may be the catalyst that transforms intentions into actual actions. According to this, we can distinguish between people with entrepreneurial motivation, but who have not yet started a business (hereafter, 'non-entrepreneurs'), and people with entrepreneurial motivation who have started and run their own business (hereafter, 'entrepreneurs'). Previous literature has studied factors that condition the development of entrepreneurial motivation by focusing mainly on either entrepreneurs (e.g. Ghalwash et al. 2017; Zwan et al. 2016) or non-entrepreneurs (e.g. Mahto \& McDowell 2018; Urban 2013). We focus on both.

\section{Hypotheses development: Institutional dimensions and components of entrepreneurial motivation in developing economies}

As the three components of entrepreneurial motivation opportunity, necessity and social - are conceptually different, the promotion of each will conceivably be associated with different institutional factors. In particular, we look first at how and why the individual's perceptions of the regulative, normative and cognitive dimensions of institutions can condition each of them.

The regulative institutions can favour different components of entrepreneurial motivation (Block \& Sandner 2009) to the extent that they establish measures that exert a push effect - for example, support for entrepreneurship among the unemployed - or pull effect - for example, favourable environments for the development of high-growth entrepreneurship - on entrepreneurship. Thus, individuals who perceive such institutions and analyse them using a rational or instrumental perspective will develop the opportunity component if they foresee profits from investing their resources (Block \& Wagner 2010), or the social component if, having such a sensitivity, they identify social problems and calculate that 
their entrepreneurial effort can simultaneously help to solve such problems and generate profits. The literature identifies institutions that exert this pull effect in developing economies. For example, the existence of a legal structure that protects private property rights (North 1990; Stenholm et al. 2013). Similarly, legislation that produces stimuli to entrepreneurship for example, tax incentives - will increase the search for business opportunities to exploit such incentives (Stenholm et al. 2013; Valdez \& Richardson 2013). In contrast, the perception of insufficient information, administrative complexities, rigid bureaucratised processes and excessive government controls can inhibit both the opportunity and social components of entrepreneurial motivation (Hechavarria \& Reynolds 2009; Urban 2013; Zwan et al. 2016).

Nevertheless, it is other factors that will be the main determinants of the necessity component of the entrepreneurial motivation. This motivation is unlikely to come from applying an instrumental logic to analysing the environment in order to identify business opportunities. Instead, if the individual uses such a logic, it will be based on the desire to find an urgent solution to their precarious situation. For example, if the individual perceives legislation guaranteeing the supply of continuous training in support of entrepreneurial activity, they could view entrepreneurship as the last resort in response to their precarious situation, increasing their motivation to start a business. Consequently, their motivation will be mainly a reaction to the push effect generated by the regulation via training programmes, rather than a proactive response based on the pull effect of the opportunities generated by the current legislation. These training initiatives could also contribute towards increasing the opportunity and social components of motivation since they support entrepreneurs, but they are not so critical in the gestation of these components in the individual. As Block and Sandner (2009) point out, when entrepreneurs pursue a business opportunity, they commit time to acquiring an overall education in multiple ways - for example, professional career, experience in the sector - so that the development of the motivation may precede the planning of the specific training activities to undertake.

Based on the above, and because the current research aims to identify the factors within the institutional environment that influence the components of entrepreneurial motivation, distinguishing those factors that forge the individual's desire to become an entrepreneur and those that actually lead them to entrepreneurial action, we posit two complementary hypotheses, one referring to non-entrepreneurs and the other to entrepreneurs (hereafter, we use $\mathrm{H}_{\mathrm{e}}$ to refer to hypotheses postulated for entrepreneurs, and $\mathrm{H}_{\mathrm{ne}}$ for hypotheses for nonentrepreneurs):

$\mathbf{H 1}_{\mathrm{ne}}$ : In a developing economy, the greater the individual's perception of regulative institutions that establish push and pull measures favourable to entrepreneurial activity, the greater the opportunity $\left(\mathrm{H}_{\mathrm{ne}}-\mathrm{a}\right)$, social $\left(\mathrm{H}_{\mathrm{ne}}-\mathrm{b}\right)$ and necessity $\left(\mathrm{H} 1_{n e}-\mathrm{c}\right)$ components of the entrepreneurial motivation that makes them desire to become an entrepreneur.

H1: In a developing economy, the greater the individual's perception of regulative institutions that establish push and pull measures favourable to entrepreneurial activity, the greater the opportunity $\left(\mathrm{H} 1_{\mathrm{e}}-\mathrm{a}\right)$, social $\left(\mathrm{H}_{\mathrm{e}}-\mathrm{b}\right)$ and necessity $\left(\mathrm{H} 1_{\mathrm{e}}-\mathrm{c}\right)$ components of the entrepreneurial motivation that leads them to entrepreneurial action.

The normative dimension includes the cultural values that individuals share in a community and that inform acceptable human and business behaviour (Scott 1995). Individuals who pay attention to what these institutions establish, apply a logic based on their desire to behave in accordance with the behavioural norms they have assimilated (Szyliowicz \& Galvin 2010). In this respect and given that the regulative institutions are unstable and ineffective in developing economies (Meyer \& Nguyen 2005; Puffer et al. 2010), the resulting uncertainty often prevents the use of instrumental logic based on the exploitation of the opportunities that the legislation generates (Huang \& Sternquist 2007). Thus, the individual needs to legitimise their motivation in cultural norms that are more stable, with the aspiration that their motivations will be acceptable to the interest groups in their community (Scott 1995). If the society to which the individual belongs views entrepreneurship as a desirable professional option and if the individual perceives this to be the case, this will favour the entrepreneurial motivation based on the pursuit of opportunities (Stenholm et al. 2013; Tominc \& Rebernik 2007; Valdez \& Richardson 2013). These normative institutions will also be relevant for constructing the social component by establishing the socially acceptable business objectives and the right ways to achieve them (Huang \& Sternquist 2007) - for example, the possibility of seeking profits and thereby satisfying a social demand. In fact, Hechavarria and Reynolds (2009) identify how values related to well-being - for example, concern for the environment generate opportunity motivation by providing the individual with a feeling of personal achievement. But this content of the normative institutions does not seem likely to favour the necessity component because individuals who are unemployed seem unlikely to start a business for nonmonetary reasons (Block \& Sandner 2009). In contrast, other cultural values, for example associated with the subsistence economy, will be able to generate this motivation - for example, social acceptance of 'homeless' businesses such as street selling. We do not study these latter normative contents in the current work because this is not a motivation that can drive development in developing economies.

Based on the above, we posit two hypotheses, referring to non-entrepreneurs and entrepreneurs respectively:

$\mathbf{H} \mathbf{2}_{\mathrm{ne}}$ : In a developing economy, the greater the individual's perception of normative institutions that lend dignity to successful, high-revenue generating entrepreneurship, the greater the opportunity $\left(\mathrm{H}_{2}-\mathrm{a}\right)$ and social $\left(\mathrm{H} 2_{n e}-b\right)$ components of the entrepreneurial motivation that makes them desire to become an entrepreneur, although these institutions will not affect the necessity component $\left(\mathrm{H} 2_{n e}-\mathrm{c}\right)$.

$\mathrm{H}_{\mathrm{e}}$ : In a developing economy, the greater the individual's perception of normative institutions that lend dignity to successful, high-revenue generating entrepreneurship, the greater the opportunity $\left(\mathrm{H}_{2} \mathrm{e}-\mathrm{a}\right)$ and social $\left(\mathrm{H}_{2} \mathrm{e}-\mathrm{b}\right)$ components of 
the entrepreneurial motivation that leads them to entrepreneurial action, although these institutions will not affect the necessity component $\left(\mathrm{H} 2 \mathrm{e}_{\mathrm{e}} \mathrm{c}\right)$.

The cognitive dimension captures the knowledge shared in an area about the ideal business practices to compete successfully (Lu 2002; Scott 1995). This knowledge can come from higher-level technical training programmes that feed the area with qualified professionals, or from the business experience of people who have started their own firms previously. Under the cognitive institutional approach, the quality of the knowledge available and of the practices of entrepreneurs is important because when individuals follow a logic based on the orthodoxy (Szyliowicz \& Galvin 2010), they will imitate or develop entrepreneurial motivations compatible with their perception of what the accumulated knowledge recommends (what they see in their environment) - for example, exploit an opportunity based on the supply of high-class hotel services, seek to make ends meet via street selling, solve social problems, etc.

In the case of the necessity component and given that the individual has not chosen entrepreneurship as a professional option voluntarily, this decision tends to be made without adequate planning (Fossen \& Büttner 2013). The individual faces high uncertainty because they have not accumulated enough knowledge resources (Block \& Wagner 2010). Lacking such knowledge (Lu 2002; Scott 1995), the individual will only develop the necessity component when the orthodox logic based on the previous business experience of others so recommends. In contrast, if the individual perceives an accumulation of high-quality business experience - that is, associated with high-growth, knowledge-based firms this will undermine the construction of an entrepreneurial motivation oriented towards low-quality businesses. Similarly, the existence of economically viable firms founded to meet social needs can encourage - via the mimetic effect the development of the social component in individuals who perceive these experiences.

Along a similar line, Manolova et al. (2008) warn that the existence of business models of growth will generate an entrepreneurial motivation based mainly on the search for opportunities, but only if the individual perceives the existence of such opportunities (García-Cabrera et al. 2016). These practices are not usual in developing economies (Valliere \& Peterson 2009), so in such countries these cognitive institutions may have a limited capacity to generate the opportunity component. In the absence of these practices, it will be the accumulation of quality knowledge acquired by individuals in advanced training programmes that awakens opportunity motivation. In these cases, as found by Lim et al. (2016), a positive, direct influence of cognitive institutions in the form of good and adequate preparation by individuals for the development of the opportunity component takes place. This knowledge not only provides the individual with resources to exploit valuable business opportunities, but also helps the individual to recognise such opportunities - for example, identify the value of the environmental information and apply it to commercial ends (Block \& Sandner 2009). These arguments may also be applicable for the social component because specialised training may awaken or inspire a greater social awareness in individuals, as found by Ghalwash et al. (2017) in their study carried out in an African developing country.

Based on the previous discussion, we hypothesise:

$\mathrm{H}_{\mathrm{ne}}$ : In a developing economy, the greater the individual's perception of cognitive institutions that concern knowledge and good business practices for successfully running their own business, the greater the opportunity $\left(\mathrm{H}_{3}-\mathrm{a}\right)$ and social $\left(\mathrm{H} 3_{n e}-\mathrm{b}\right)$ components of the entrepreneurial motivation that makes them desire to become an entrepreneur, but the lesser the necessity component $\left(\mathrm{H} 3_{\text {ne }}-\mathrm{c}\right)$.

H3: In a developing economy, the greater the individual's perception of cognitive institutions that concern knowledge and good business practices for successfully running their own business, the greater the opportunity $\left(\mathrm{H}_{3}-\mathrm{a}\right)$ and social $\left(\mathrm{H}_{\mathrm{e}}-\mathrm{b}\right)$ components of the entrepreneurial motivation that leads them to entrepreneurial action, but the lesser the necessity component $\left(\mathrm{H}_{\mathrm{e}}-\mathrm{c}\right)$.

Finally, we can make further considerations referring to the relevance of the institutional dimension on the development of individuals' entrepreneurial motivation, distinguishing between entrepreneurs and non-entrepreneurs. Previous literature suggests that in the absence of developed regulative frameworks to facilitate business activities and the unstable character of regulation in developing economies (Meyer \& Nguyen 2005), there is a greater development of commonly accepted customs and habits - the normative and cognitive institutions (Puffer et al. 2010). So, we can expect that normative and cognitive institutions will be considered to a greater degree by individuals, and hence will be more able to affect their entrepreneurial motivation, because these aspects of institutions are more trustworthy (García-Cabrera et al. 2016). Indeed, some authors have found that while cognitive and normative institutions condition the level to which individuals engage in entrepreneurship in developing economies (i.e. individuals develop activities of not only opportunity recognition, but also evaluation, or even exploitation), regulative institutions do not have such a direct influence (e.g. Lim et al. 2016). However, distinctions between the normative and cognitive dimensions of institutions can also be made.

Firstly, as the normative dimension reflects the degree to which a society believes that starting a new business is worthy and valuable to society, and so provides societal legitimation to business activities (Stenholm et al. 2013; Urban 2013), these aspects of institutions may condition the individual's perception of entrepreneurship as a desirable career choice (Lim et al. 2016). In this respect, Krueger, Reilly and Carsrud (2000) state that the beliefs and expectations of a social reference group will affect individuals' entrepreneurial desires and intentions. So, we can expect that normative institutions are especially relevant for generating entrepreneurial motivation among non-entrepreneurs. 
Secondly, as the cognitive dimension captures the knowledge shared in an area about the ideal business practices to compete successfully, coming from either technical training programmes or aggregate business experience in the area $(\mathrm{Lu}$ 2002; Scott 1995), these aspects of institutions may equip individuals with the required resources to identify business opportunities (Urban 2013), estimate a level of performance and have confidence in that level (Stenholm et al. 2013), and so reduce perceptions of risk associated with the exploitation of such identified opportunities (Lim et al. 2016). Thus, cognitive institutions may influence entrepreneurial motivation because they nurture the individuals with the criteria to perceive and truly exploit opportunities in the marketplace, all of it necessary to engage in entrepreneurship by starting a firm. So, we can posit the following hypotheses:

$\mathrm{H} 4_{\mathrm{ne}}$ : In a developing economy, perceptions of normative institutions that lend dignity to successful, high-revenue generating entrepreneurship, rather than those of cognitive and regulative institutions, will condition the development of entrepreneurial motivation that makes the individual desire to become an entrepreneur.

H4: In a developing economy, perceptions of cognitive institutions that concern knowledge and good business practices to successfully run one's own business, rather than those of normative and regulative institutions, will condition the development of entrepreneurial motivation that leads the individual to entrepreneurial action.

\section{Research design and methodology}

The current research adopts a deductive approach in order to test the validity of the hypotheses posited above. The study bases itself on quantitative data and data collection was carried out making use of a survey. Specifically, data collection was used to gather the information from two subsamples of resident entrepreneurs and non-entrepreneurs in a developing economy, which was required to evaluate the hypotheses and reach the research objective. Further details about research design and methodology are provided below.

\section{The setting: Cape Verde background}

Cape Verde is an African country that, according to the country classification elaborated on the basis of the World Economic Situation and Prospects (WESP), is classified as a developing economy (United Nations 2014). The country is one of the few democratic and politically stable nations on the African continent, and also one of the fastest growing economies after the liberalisation of its economy in the 1990s with the establishment of independent regulation, the privatisation of public firms and the institutionalisation of a democratic regime. Successive governments have implemented policies aimed at incentivising firm creation and hence strengthening the national business fabric and the private sector. As a result of these efforts, Cape Verde was considered one of the 10 best reformers in Africa in 2010, with the country showing positive social, economic and political indicators, particularly in comparison to other countries in West Africa. Currently, the macro-economic indicators at the aggregate level for the country point to a favourable general environment, with a real gross domestic product (GDP) growth of 3.89\% from 2016 to 2017. According to Cape Verde's National Statistics Institute (INE 2017), the tertiary sector makes up $61.6 \%$ of the economy (i.e. real GDP), followed by secondary $(17.3 \%)$ and primary $(7.5 \%)$ sectors. Within the tertiary sector, real estate services (9.92\%), trade $(9.63 \%)$ and transports $(8.88 \%)$ are the most relevant subsectors, whereas tourism - accommodation and catering reaches $4.1 \%$ of real GDP.

Despite the mentioned advances, Cape Verde still faces significant structural challenges such as poverty (for example one in four individuals is considered poor, surviving on less than US\$2 per day). With respect to the Human Development Index, Cape Verde reached a value of 0.648 in 2016 (it ranks 122 out of 188 countries, and it is number 10 when considered on the list of African countries by Human Development Index). As in other developing economies, the business people and entrepreneurs in Cape Verde suffer from a weak institutional environment characterised by (UCRE \& UNIDO 2011): (1) the ineffectiveness of the regulative institutions and the legal system and (2) problems with the public administration, such as the low level of qualifications of many public employees, and the slow processes and bureaucracy. But there are other problems too, concerning: (1) transport, (2) qualifications of the workforce, (3) the electricity supply, (4) access to credit and (5) informal competitors.

\section{Population, sampling procedure and data collection}

The population we are studying consists of the entire active population of Cape Verde (people between 15 and 64 years old). According to INE (2011), the universe of study comprises 491875 people in 2010 (infinite population), so that accepting a confidence level of $95.5 \%$ and sampling error rate of $4.5 \%$ the defined sample size is 247. After carrying out the fieldwork in June 2012, we obtained a final sample of 237 (valid questionnaires), hence sampling error slightly raised to $4.59 \%$. The study was carried out on 6 of the 10 islands of the archipelago (Sal, Boavista, Santiago, Sao Vicente, Fogo and Maio), and to collect the information we used a structured questionnaire written in Portuguese, which we pretested previously. We used stratified sampling with proportional allocation for the variables concelho, gender, age and education. In addition, a quota was set up for entrepreneurs (40\%) and non-entrepreneurs (60\%) in order to guarantee the presence of enough individuals in the two subsamples to test the posited hypotheses.

The procedure for carrying out data collection was the following: we first chose nine survey takers who were university students and spoke both the official languages of the country (Portuguese, which is learned at school) and Crioulo (a common dialect used in daily life, especially by the section of the population with a lower educational level). 
These survey takers were instructed about terms and items in the questionnaire. Later on, for the data collection, personal and direct surveys were carried out on public highways and areas of population movement, among them markets, public squares and so on. Different routes were established for each survey taker.

\section{Reliability and validity of measurements}

The questionnaire included items referring to entrepreneurial motivation and perceptions on institutional factors, as well as demographic issues. We measured all except the demographic variables using a 5-point Likert scale, where the maximum value indicates respondents' total agreement with the statement.

\section{Dependent variables}

We measured entrepreneurial motivation using 11 items based on Williams (2009) for the opportunity and necessity components, Renko (2013) for the social component, and Birley and Westhead (1994) for all three components (Appendix 1). In order to assess the internal reliability of items in this scale, the Cronbach's alpha coefficient was calculated for the subsamples of both entrepreneurs and nonentrepreneurs, and we obtained values of 0.774 and 0.686 , respectively. Validity of the scale was measured through content validity and construct validity. To ensure content validity, we first carried out an exhaustive literature review on the topic. Later on, we asked for an expert review from three qualified researchers in the field of entrepreneurship and research methodology, their feedback being considered in the formulation of the final research instrument. Construct validity was verified through the convergent validity of the scale and by analysing the components' loadings (Appendix 1). Specifically, a principal components factor analysis with varimax rotation confirms the homogeneity of the scale for both subsamples: entrepreneurs (KMO = 0.710; $\chi^{2}=290.144 ;$ variance explained $=70.5 \%$ ) and nonentrepreneurs $\left(\mathrm{KMO}=0.702 ; \chi^{2}=214.897\right.$; variance explained $=61 \%)$. For the sample of non-entrepreneurs, we identify only two components, opportunity (alpha $=0.607$; variance explained $=25.4 \%$ ) and necessity (alpha $=0.782$; variance explained $=35.6 \%$ ). For the subsample of entrepreneurs, we identify the three expected components of entrepreneurial motivation, that is, opportunity (alpha $=0.751$; variance explained $=23.2 \%$ ), necessity (alpha $=0.706$; variance explained $=21.4 \%$ ) and social (alpha $=0.780$; variance explained $=25.9 \%$ ). All the components loadings show scores that range from 0.463 (in the non-entrepreneur subsample) to 0.912 (in the entrepreneur subsample).

\section{Independent variables}

The information about the institutional dimensions was collected using a multiple-item scale that included 30 items (Appendix 2). For the normative institutions, we used six items from Tominc and Rebernik's (2007) scale. We built the regulative and cognitive scales in coherence with the most recent versions of new institutionalism, the aim being to make them measurable via individual perceptions. We followed authors who have previously measured these variables, in particular Busenitz et al.'s (2000) proposal, which Manolova et al. (2008) successfully replicate. Internal reliability of 30 items in this scale was assessed by the Cronbach's alpha coefficient in the subsamples of entrepreneurs and nonentrepreneurs, obtaining values of 0.864 and 0.798, respectively. Content validity was ensured by an exhaustive literature review on the topic and a subsequent expert review from the three qualified researchers mentioned above, whose feedback was considered in the design of the final research instrument. Finally, construct validity was tested through the convergent validity of the scale and by analysing the components' loadings (Appendix 2). In detail, for the two subsamples of entrepreneurs and nonentrepreneurs, a principal components factor analysis with varimax rotation confirms the homogeneity of the scales $\left(\mathrm{KMO}=0.706, \chi^{2}=907.975\right.$, variance explained $=71.5 \%$ and $\mathrm{KMO}=0.746, \chi^{2}=1171.470$, variance explained $=67 \%$, respectively). For the subsample of entrepreneurs, we obtain: (1) two factors relating to the cognitive institutions: educated population available (alpha $=0.813$; variance explained $=$ $11.9 \%$ ) and local business experience (alpha $=0.762$; variance explained $=11.2 \%$ ), (2) four factors for the regulative institutions: legal incentive for entrepreneurship (alpha = 0.668 ; variance explained $=9.5 \%$ ), continuing training opportunities (alpha $=0.717$; variance explained $=9.4 \%$ ), flexible labour legislation (alpha $=0.853$; variance explained $=$ $8.9 \%$ ), and government control of quality (alpha $=0.730$; variance explained $=7.8 \%$ ), (3) and one factor for the normative institutions: entrepreneur's image and social status (alpha $=0.778$; variance explained $=12.8 \%$ ). For the subsample of non-entrepreneurs, we obtain: (1) three factors relating to the cognitive institutions: educated population available (alpha $=0.815$; variance explained $=12.9 \%$ ), local business experience $($ alpha $=0.839$; variance explained $=$ $7.8 \%$ ), and mimetic pressure (alpha $=0.716$; variance explained $=7.2 \%)$, (2) three factors for the regulative institutions: legal incentive for entrepreneurship (alpha = 0.791 ; variance explained $=10.9 \%$ ), continuing training opportunities (alpha $=0.722$; variance explained $=9.2 \%$ ) and flexible labour legislation (alpha $=0.707$; variance explained $=$ $8.9 \%$ ), and (3) one factor for the normative institutions: entrepreneur's image and social status (alpha $=0.730$; variance explained $=10.1 \%$ ). All the components' loadings show scores that range from 0.545 to 0.850 , both displayed in the non-entrepreneur subsample.

\section{Control variables}

On the basis of the previous literature (e.g. Block \& Sandner 2009; Block \& Wagner 2010; Fossen \& Büttner 2013; Jayawarna et al. 2013) we use the following control variables: individual's age, number of relatives who depend economically on the individual, and education (1- none, 2- primary, 3- secondary, and 4- tertiary).

\section{Data analysis}

After using principal components factor analysis with varimax rotation, we obtained synthetic indicators of 
institutional dimensions and components of entrepreneurial motivation. The standardised values ( mean $=0$, standard deviation $=1$ ) of these indicators were used in the further analyses. Specifically, we first carried out a correlation analysis between the independent variables (i.e. control variables and synthetic indicators) and later we used multiple linear regression analysis to test the hypotheses. For the entrepreneurs, we estimated three models, one for each component of entrepreneurial motivation, and for the nonentrepreneurs we estimated two models, one for each of the opportunity and necessity components. We evaluated the potential instability of the regression coefficients using a multicollinearity diagnosis. Finally, the current research is cross-sectional and uses a single source of data, which could give rise to common method variance. To minimise this risk, we guaranteed the respondents' anonymity, pretested the questionnaire and tested for the existence of common method variance, using Harman's one factor, which is one-technique based on factor analysis to check if the majority of the variance (more than $50 \%$ ) can be explained by a single factor (Podsakoff \& Organ 1986). Harman's test does not identify the existence of common method variance in both subsamples. For entrepreneurs, the test finds nine factors with eigenvalues greater than 1 , whether we run the principal components factor analysis unrotated (variance explained $=71.6 \%$ ), or with varimax rotation (variance explained $=71.6 \%$ ), or a principal axis factor analysis with varimax rotation (variance explained $=61.1 \%$ ). The first factor obtained in each of these estimations explains $22.8 \%, 10.4 \%$ and $9.8 \%$ of the total variance, respectively. For non-entrepreneurs, Harman's test identifies 10 factors with eigenvalues greater than 1 , whether we run the principal components factor analysis unrotated (variance explained $=70.48 \%$ ), or with varimax rotation (variance explained $=70.48 \%$ ), or a principal axis factor analysis with varimax rotation (variance explained $=56.8 \%$ ). The first factor obtained in each of these analyses explains $15.8 \%, 10.1 \%$ and $8.8 \%$ of the total variance, respectively.

\section{Results \\ Sample description}

Sample proportions and quotas were highly met for the variables concelho, gender, age and education (Table 1), as well as quotas for entrepreneurs and non-entrepreneurs. Specifically, the sample has roughly equal numbers of men and women $(50.2 \%-49.8 \%)$, and their average age is 34 . With regard to education, $6.3 \%$ have no formal education, while $36.7 \%$ have a primary, $44.3 \%$ a secondary, and $12.2 \%$ a university education. In addition, $39.2 \%$ of the sample (93 individuals) currently own a firm, while $60.76 \%$ (144 individuals) are non-entrepreneurs, either employed or unemployed.

The firms founded by the entrepreneurs are on average five years old and employ 10.06 people. The most common sectors are the catering industry $(18.3 \%)$, trade $(15.1 \%)$, transport $(11.8 \%)$, leisure $(8.6 \%)$, hotels $(7.5 \%)$, and travel operators $(4.3 \%)$, while less common sectors include professional services, industry, agriculture or construction. With regard to the founder's profile, $52.7 \%$ of these are male and they have an average age of 39.07 .

Table 2 and Table 3 show the means, standard deviations and correlations between the independent and control variables in the subsamples of non-entrepreneurs and entrepreneurs, respectively. As we use synthetic indicators of institutional dimensions and components of entrepreneurial motivation obtained from principal components factor analysis, their means and standard deviations (SD) correspond to standardised values (mean $=0, \mathrm{SD}=1$ ).

\section{Findings: Hypotheses test}

Table 4 (Model 1 and Model 3) shows the regressions estimated for the non-entrepreneurs. As we only identified two components of entrepreneurial motivation for this subsample, that is, the opportunity and necessity components, hypotheses referring to the social component cannot be tested $\left(\mathrm{H} 1_{n e}-\mathrm{b}, \mathrm{H} 2_{n e}-\mathrm{b}\right.$ y $\left.\mathrm{H} 3_{n e}-\mathrm{b}\right)$. Results show that the individual's perception of the regulative institutions influences the opportunity (Model 1) and necessity components (Model 3) as proposed in $\mathrm{H}_{n e}{ }^{-\mathrm{a}}$ and $\mathrm{H} 1_{n e}{ }^{-\mathrm{c} \text {. The }}$ results show that when the individual perceives incentives for entrepreneurship, the necessity component increases, while the perception of legislation guaranteeing support for

TABLE 1: Sample distribution.

\begin{tabular}{|c|c|c|c|c|}
\hline \multirow[t]{2}{*}{ Stratification criteria } & \multicolumn{2}{|c|}{ Population } & \multicolumn{2}{|c|}{ Final sample } \\
\hline & $\mathbf{N}$ & $\%$ & $\mathbf{N}$ & $\%$ \\
\hline \multicolumn{5}{|l|}{ Concelho (Island) $\dagger$} \\
\hline \multicolumn{5}{|l|}{ Santiago: } \\
\hline Praia & 85576 & 42.40 & 100 & 42.19 \\
\hline Ribeira Grande & 11103 & 5.50 & 14 & 5.91 \\
\hline Tarrafal & 10513 & 5.21 & 9 & 3.8 \\
\hline Sao Vicente & 50029 & 24.79 & 58 & 24.47 \\
\hline Sal & 17625 & 8.73 & 22 & 9.28 \\
\hline Boavista & 6546 & 3.24 & 8 & 3.38 \\
\hline Maio & 4270 & 2.12 & 6 & 2.53 \\
\hline \multicolumn{5}{|l|}{ Fogo: } \\
\hline Sao Filipe & 13227 & 6.55 & 16 & 6.75 \\
\hline Santa Catarina & 2921 & 1.45 & 4 & 1.69 \\
\hline Total & 201810 & 100 & 237 & 100 \\
\hline \multicolumn{5}{|l|}{ Gender } \\
\hline Male & 102664 & 50.87 & 119 & 50.21 \\
\hline Female & 99146 & 49.13 & 118 & 49.79 \\
\hline Total & 201810 & 100 & 237 & 100 \\
\hline \multicolumn{5}{|l|}{ Age } \\
\hline $15-30$ & 106944 & 52.99 & 123 & 51.90 \\
\hline $31-45$ & 59006 & 29.24 & 71 & 29.96 \\
\hline $46-64$ & 35860 & 17.77 & 41 & 17.30 \\
\hline Not available & - & - & 2 & 0.84 \\
\hline Total & 201810 & 100 & 237 & 100 \\
\hline \multicolumn{5}{|l|}{ Education } \\
\hline None & 12779 & 6.39 & 15 & 6.33 \\
\hline Primary & 78620 & 39.29 & 87 & 36.71 \\
\hline Secondary & 86254 & 43.10 & 105 & 44.30 \\
\hline Tertiary & 22463 & 11.22 & 29 & 12.24 \\
\hline Not available & 1694 & - & 1 & 0.42 \\
\hline Total & 201810 & 100 & 237 & 100 \\
\hline
\end{tabular}

$\dagger$, Larger islands are divided into different concelhos (Cape Verdean municipalities), but in the case of the smaller ones, the island and the concelho coincide. 
TABLE 2: Correlations, means and standard deviations: Non-entrepreneurs subsample.

\begin{tabular}{|c|c|c|c|c|c|c|c|c|c|c|}
\hline Variable & 1 & 2 & 3 & 4 & 5 & 6 & 7 & 8 & 9 & 10 \\
\hline 1. Age & 1 & - & - & - & - & - & - & - & - & - \\
\hline 2. Number of dependents & $0.430 * * *$ & 1 & - & - & - & - & - & - & - & - \\
\hline 3. Education & 0.046 & -0.069 & 1 & - & - & - & - & - & - & - \\
\hline 4. Entrepreneur's image and social status (F1.Nor.) & $-0.206 *$ & -0.049 & -0.100 & 1 & - & - & - & - & - & - \\
\hline 5. Educated population available (F1.Cog.) & -0.030 & -0.094 & 0.035 & 0.000 & 1 & - & - & - & - & - \\
\hline 6. Local business experience (F2.Cog.) & -0.014 & -0.069 & $-0.166 *$ & 0.000 & 0.000 & 1 & - & - & - & - \\
\hline 7. Mimetic pressure (F3.Cog.) & -0.079 & 0.033 & $-0.192 *$ & 0.000 & 0.000 & 0.000 & 1 & - & - & - \\
\hline 8. Legal incentive for entrepreneurship (F1.Reg.) & -0.033 & 0.004 & 0.103 & 0.000 & 0.000 & 0.000 & 0.000 & 1 & - & - \\
\hline 9. Training opportunities (F2.Reg.) & 0.084 & -0.043 & -0.129 & 0.000 & 0.000 & 0.000 & 0.000 & 0.000 & 1 & - \\
\hline 10. Flexible labour legislation (F3.Reg.) & 0.069 & 0.046 & 0.000 & 0.000 & 0.000 & 0.000 & 0.000 & 0.000 & 0.000 & 1 \\
\hline Mean & 30.7 & 1.5 & 2.6 & 0.0 & 0.0 & 0.0 & 0.0 & 0.0 & 0.0 & 0.0 \\
\hline Standard deviation & 11.4 & 1.8 & 0.8 & 1.0 & 1.0 & 1.0 & 1.0 & 1.0 & 1.0 & 1.0 \\
\hline
\end{tabular}

$*, p<0.05 ; * * *, p<0.001$.

TABLE 3: Correlations, means and standard deviations: Entrepreneurs subsample.

\begin{tabular}{|c|c|c|c|c|c|c|c|c|c|c|}
\hline Variable & 1 & 2 & 3 & 4 & 5 & 6 & 7 & 8 & 9 & 10 \\
\hline 1. Founder age & 1 & - & - & - & - & - & - & - & - & - \\
\hline 2. Number of dependents & $0.204 *$ & 1 & - & - & - & - & - & - & - & - \\
\hline 3. Founder education & $-0.174 *$ & -0.025 & 1 & - & - & - & - & - & - & - \\
\hline 4. Entrepreneur's image and social status (F1.Nor.) & $0.178^{*}$ & -0.056 & -0.067 & 1 & - & - & - & - & - & - \\
\hline 5. Qualified population available (F1.Cog.) & 0.001 & 0.078 & -0.039 & 0.000 & 1 & - & - & - & - & - \\
\hline 6. Local business experience (F2.Cog.) & 0.040 & 0.118 & $-0.313 * *$ & 0.000 & 0.000 & 1 & - & - & - & - \\
\hline 7. Legal incentive for entrepreneurship (F1.Reg.) & -0.020 & 0.073 & 0.133 & 0.000 & 0.000 & 0.000 & 1 & - & - & - \\
\hline 8. Training opportunities (F2.Reg.) & 0.114 & 0.053 & 0.099 & 0.000 & 0.000 & 0.000 & 0.000 & 1 & - & - \\
\hline 9. Flexible labour legislation (F3.Reg.) & 0.089 & -0.123 & -0.155 & 0.000 & 0.000 & 0.000 & 0.000 & 0.000 & 1 & - \\
\hline 10. Government control of quality (F4.Reg.) & -0.029 & 0.171 & -0.089 & 0.000 & 0.000 & 0.000 & 0.000 & 0.000 & 0.000 & 1 \\
\hline Mean & 39.1 & 2.9 & 2.7 & 0.0 & 0.0 & 0.0 & 0.0 & 0.0 & 0.0 & 0.0 \\
\hline Standard deviation & 10.125 & 1.807 & 0.763 & 1.0 & 1.0 & 1.0 & 1.0 & 1.0 & 1.0 & 1.0 \\
\hline
\end{tabular}

$*, p<0.1 ; * *, p<0.01$.

entrepreneurship via continuing training opportunities favours the opportunity component. Thus, $\mathrm{H} 1_{n e}-\mathrm{a}$ and $\mathrm{H} 1_{n e}-\mathrm{c}$ can be accepted. In turn, when the individual perceives normative institutions that bestow a positive image and status on entrepreneurs, the opportunity and necessity components increase. These results offer support for $\mathrm{H} 2{ }_{n e}-\mathrm{a}$, but not $\mathrm{H} 2_{n e}-\mathrm{c}$, an unexpected statistical significance being obtained for the latter.

With respect to the cognitive institutions, when the individual perceives that there are individuals nearby with business experience, the necessity component increases, but the opportunity component remains unaffected. Thus, $\mathrm{H} 3_{n e}-\mathrm{c}$ can be rejected, because the sign is the opposite to what we expected. We should take note that this hypothesis refers to high-quality business experience, which is uncommon in developing economies. Thus, knowing people who have started ventures merely to survive will encourage others to do the same and with the same motivation, but the opportunity component will not be affected. Thus, $\mathrm{H} 3_{n e}$-a can be rejected since the available, well-educated sections of the population do not have a positive effect on the opportunity component either, as we initially expected.

Table 4 (Models 2, 4 and 5) shows the regressions estimated to analyse how the individual's perceptions of the institutions affect each component of entrepreneurial motivation in the subsample of entrepreneurs. The entrepreneurs' perception of the regulative institutions conditions the opportunity
(Model 2) and necessity components (Model 4) as proposed in hypotheses $\mathrm{H}_{e}-\mathrm{a}$ and $\mathrm{H}_{e}-\mathrm{c}$, respectively, but not the social component (Model 5), meaning we can reject $\mathrm{H} 1_{e}-\mathrm{b}$. These results show that when the entrepreneurs perceive laws and regular controls by the administration to ensure the quality of firms' products and services, the opportunity component of their entrepreneurial motivation falls, and the perception of incentives under that legislation does not incentivise this motivation. Thus, $\mathrm{H}_{e}$-a is rejected. The necessity component is favoured by the perceived existence of legislation, guaranteeing the support of entrepreneurship via the offer of continuing training opportunities, so $\mathrm{H} 1_{e}-\mathrm{c}$ finds support in these data.

On the other hand, when the entrepreneurs perceive normative institutions that bestow a positive image and status on those who start businesses, the opportunity and social components increase, but the necessity component remains unaffected. These results offer support for hypotheses $\mathrm{H} 2{ }_{e}-\mathrm{a}, \mathrm{H} 2{ }_{e}-\mathrm{b}$ and $\mathrm{H} 2{ }_{e}-\mathrm{c}$. Finally, concerning the cognitive institutions, while the perception of individuals in the vicinity with business experience does have a positive effect on the necessity and social components, it is the belief that an educated workforce is available in the area that strengthens the entrepreneur's opportunity motivation. These results provide support for $\mathrm{H}_{e}-\mathrm{a}, \mathrm{H}_{e}-\mathrm{b}$ and $\mathrm{H}_{3}-$-c. All these results are summarised and depicted in Figure 1.

Finally, and considering the obtained values for standardised beta coefficients, results show that whereas the normative 
TABLE 4: Results of estimated models for components of entrepreneurial motivation: Entrepreneurs and non-entrepreneurs subsamples.

\begin{tabular}{|c|c|c|c|c|c|}
\hline \multirow[t]{2}{*}{ Variables } & \multicolumn{2}{|c|}{ Opportunity } & \multicolumn{2}{|c|}{ Necessity } & \multirow{2}{*}{$\begin{array}{l}\text { Social: Entrepreneurs } \\
\text { Model } 5(\beta)\end{array}$} \\
\hline & $\begin{array}{c}\text { Non-entrepreneurs } \\
\text { Model } 1(\beta)\end{array}$ & $\begin{array}{l}\text { Entrepreneurs } \\
\text { Model } 2(\beta)\end{array}$ & $\begin{array}{l}\text { Non-entrepreneurs } \\
\text { Model } 3(\beta)\end{array}$ & $\begin{array}{c}\text { Entrepreneurs } \\
\text { Model } 4(\beta)\end{array}$ & \\
\hline \multicolumn{6}{|l|}{ Control variables } \\
\hline Founder age & 0.011 & -0.114 & -0.072 & $-0.271 *$ & -0.034 \\
\hline Number of dependents & 0.013 & 0.096 & 0.123 & -0.001 & $0.196 \dagger$ \\
\hline Founder education & 0.114 & 0.012 & $-0.234 *$ & -0.160 & $0.311 * *$ \\
\hline \multicolumn{6}{|l|}{ Normative dimension } \\
\hline Entrepreneur's image and social status & $0.309 * *$ & $0.299 * *$ & $0.287 * *$ & -0.090 & $0.214 \dagger$ \\
\hline \multicolumn{6}{|l|}{ Cognitive dimension } \\
\hline Educated population available & -0.029 & $0.310 * *$ & 0.063 & -0.132 & -0.018 \\
\hline Local business experience & 0.009 & 0.153 & $0.174^{*}$ & $0.261^{*}$ & $0.371 * * *$ \\
\hline Mimetic pressure & -0.060 & - & 0.025 & - & - \\
\hline \multicolumn{6}{|l|}{ Regulative dimension } \\
\hline Legal incentive for entrepreneurship & -0.135 & -0.072 & $0.303 * *$ & -0.042 & -0.021 \\
\hline Flexible labour legislation & 0.064 & 0.134 & 0.121 & -0.023 & -0.032 \\
\hline Government control of quality & - & $-0.231 *$ & - & 0.056 & -0.016 \\
\hline Adjusted $R^{2}$ & $9.4 \%$ & $20.9 \%$ & $20.9 \%$ & $11.2 \%$ & $15.8 \%$ \\
\hline $\mathrm{F}$ & $2.145^{*}$ & $3.064 * *$ & $3.899 * * *$ & $1.980 *$ & $2.461 *$ \\
\hline Durbin-Watson & 2.098 & 2.406 & 2.160 & 2.134 & 1.826 \\
\hline Condition number & 10.789 & 15.113 & 10.789 & 15.113 & 15.113 \\
\hline VIF (Min-Max) & $1.010-1.372$ & $1.022-1.289$ & $1.010-1.372$ & $1.022-1.289$ & $1.038-1.289$ \\
\hline$N$ & 111 & 79 & 111 & 79 & 79 \\
\hline
\end{tabular}

$\dagger, p<0.1 ; *, p<0.05 ; * *, p<0.01 ; * * *, p<0.001$.

$\mathrm{R}^{2}$, adjusted R-squared; F, F-test of overall significance in regression analysis; VIF, variance inflation factor; $N$, number of individuals.

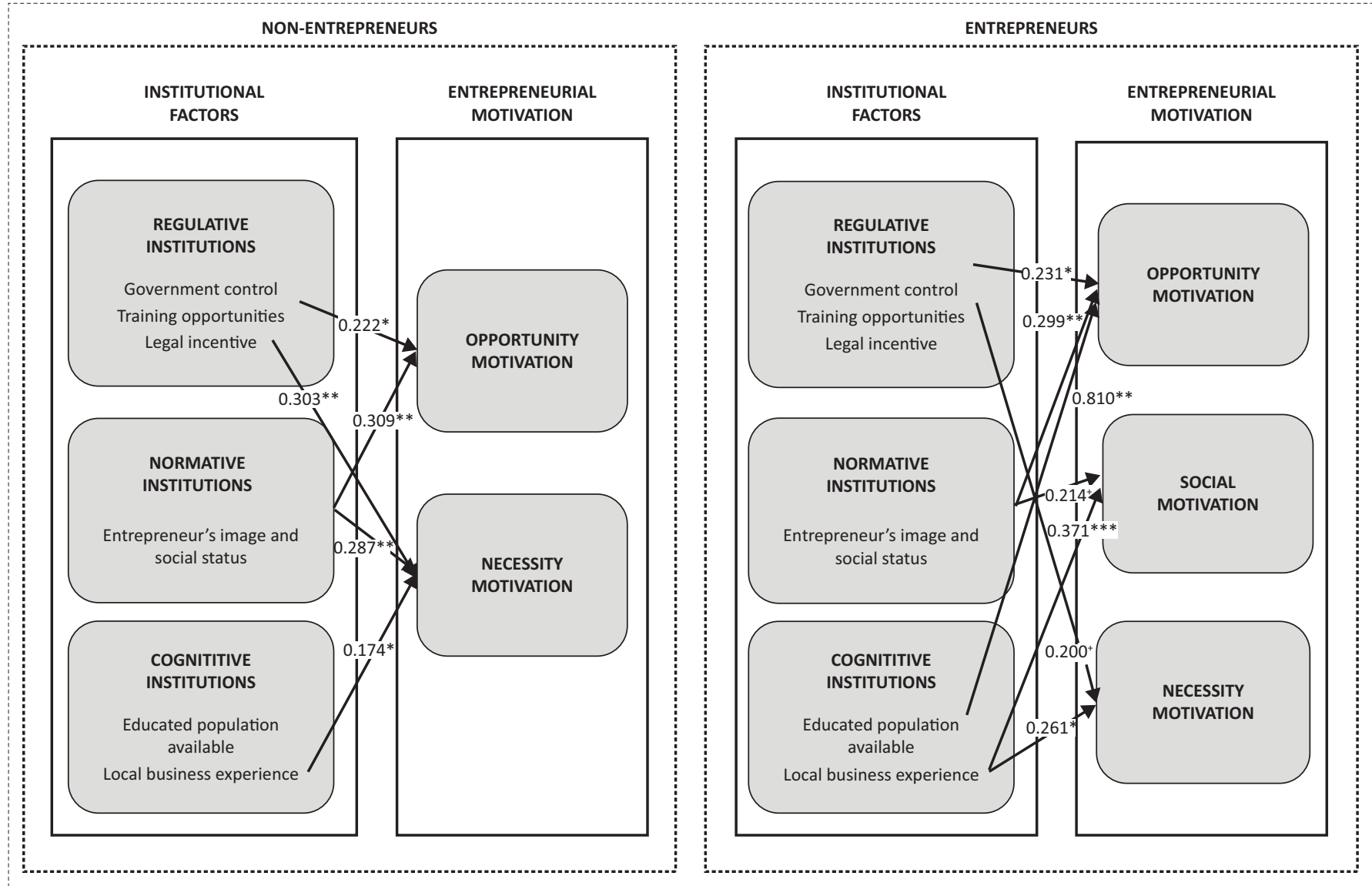

FIGURE 1: Influence of institutional perception on construction of entrepreneurial motivations. 
dimension of institutions condition to a greater degree the opportunity component of the entrepreneurial motivation of non-entrepreneurs, there are aspects of the regulative institutions that influence the necessity component more strongly. Thus, $\mathrm{H} 4_{n e}$ must be rejected as we only find support for one component of the entrepreneurial motivation of non-entrepreneurs. Concerning entrepreneurs, we found that cognitive aspects of institutions are more relevant than the normative and regulative ones in their influence on entrepreneurial motivation, irrespective of the component of entrepreneurial motivation considered, that is, opportunity, social and necessity. So, $\mathrm{H}_{4}$ finds support.

\section{Discussion}

The current research identifies the institutional factors that explain the entrepreneurial motivation driving the individual's desire to become an entrepreneur or actually leading them to entrepreneurial action in a developing economy, distinguishing between three components of entrepreneurial motivation: opportunity, necessity and social. Neo-institutionalism (Greenwood \& Hinings 1996) provides the theoretical foundations for this study. Our findings suggest that how the entrepreneur perceives the institutional dimensions will affect the components of their entrepreneurial motivation. In contrast to the early approach to new institutionalism, which analyses how the environment determines the individual's behaviour, our results are coherent with Valdez and Richardson (2013) or García-Cabrera et al. (2016) and support the thesis that room exists for individual discretion. This explains why, when faced with the same institutional framework, different individuals construct - to varying degrees - each component of entrepreneurial motivation - opportunity, necessity and social. In addition, this study allows us to elucidate whether or not the same institutional factors generate the entrepreneurial motivation that forges an individual's desire to be an entrepreneur and the motivation that leads them to actually set up their own business. Our findings show that they are not the same.

\section{Components of entrepreneurial motivation in entrepreneurs and non-entrepreneurs}

Entrepreneurs and non-entrepreneurs in a developing economy can be clearly distinguished by the components of their entrepreneurial motivation. The current work has identified three differentiated motivational components for entrepreneurs, but only two for the non-entrepreneurs, with the main difference between the two groups being the presence or absence of the social component of motivation.

Firstly, the arguments based on the interest in creating jobs in the community or the commitment to family members and friends - both associated with the social component - explain the existence of a motivational factor in the group of entrepreneurs. But this component cannot be identified for the non-entrepreneurs. This last group of individuals have two main motivational factors - opportunity and necessity - which are also present for the entrepreneurs. This difference can be explained on the basis of the conceptual distinction between the components. Thus, unlike the personal focus inherent in the reasons to become an entrepreneur found among the opportunity and necessity components - for example, desire for wealth, finding a means of sustenance the social component corresponds more to reasons of moral responsibility towards the community (Ghalwash et al. 2017; Mair \& Martí 2006). These results suggest that it is mainly personal reasons that generate the desire to be an entrepreneur in developing economies. In contrast, concern for others that is, for the needs of the community - takes on a role in the path that the individual takes from the initial state of wanting to become an entrepreneur to actual entrepreneurial action in a developing economy. Embarking on entrepreneurship is often seen as a way of helping or creating jobs for one's people: family members, close friends and acquaintances. In this respect, we should underline that both the concept and the scope of the family are very broad in many developing economies such as Cape Verde. The family goes beyond blood ties to include other, more distant relatives, friends, and even members of the individual's community of origin or residence. So, our work adds to others that have found an increased relevance of the social component of entrepreneurial motivation in the less-advanced economies (e.g. Azmat 2013) and factors that influence such motivation among entrepreneurs (Ghalwash et al. 2017), because we found that social reasons are unlikely to be present at the initial emergence of entrepreneurial motivation, but these reasons acquire an increased relevance in the path to entrepreneurial action.

\section{Institutional perceptions and the entrepreneurial motivation in entrepreneurs and non- entrepreneurs}

The current work identifies how the individual's perception of institutional factors favours the different components of their entrepreneurial motivation, both for individuals who have actually acted on their entrepreneurial motivation and started a firm and for individuals whose motivation has not yet led them to start a firm.

The social component develops in the entrepreneur who perceives in their community consolidated business practices that guide their actions. Similarly, the fact that the community has a high opinion of entrepreneurship as a professional option also incentivises their social motivation. Thus, it is the forms of logic based on orthodoxy and morality (Szyliowicz \& Galvin 2010), respectively, that condition this component, compared to the instrumental logic based on a rational actor who analyses the opportunities provided by the regulative institutions. In fact, neither the legal incentives for entrepreneurship, nor the training courses seem to affect the development of the social component among the entrepreneurs.

In the development of the opportunity component of the entrepreneur's motivation, the individual's perception of all 
the institutional dimensions has an impact, so the results suggest that its gestation could be the most demanding. The individual constructs this component when they perceive in their area: (1) advanced, high-quality knowledge acquired in the classroom, (2) cultural values that lend dignity to the entrepreneur's work, and (3) legislation that does not necessarily incentivise entrepreneurship, but that at least does not inhibit it through its inefficiencies. For the case of the non-entrepreneurs, the opportunity component seems to be conditioned by similar, though not identical, factors. Firstly, and coinciding with the entrepreneurs, they seem to need to perceive cultural values that lend dignity to the entrepreneur's work. Secondly, rather than the existence of advanced knowledge acquired in the classroom and not conditioned by local business practices, what conditions the construction of the opportunity component is the availability of training that provides workers ready for hire, as well as training courses for starting a business. Consequently, the results suggest the importance of the knowledge and skills of the workforce in the development of the opportunity component. But while it is important for the entrepreneurs to perceive that there is an educated population available (cognitive dimension), what is important for the nonentrepreneurs is the perception of the availability of training courses (regulative dimension). It seems to be facts rather than possibilities that entrepreneurs, through their executive vision, base their motivations on. Finally, it is interesting to note that the perception of incentives for entrepreneurship provided by the regulative institutions does not generate the opportunity component, either among entrepreneurs or non-entrepreneurs, in contrast to what many governments would expect.

In regard to the necessity component of motivation, important differences between the entrepreneurs and non-entrepreneurs can be identified. For the entrepreneurs, this motivation is positively conditioned by regulative institutions that offer continuous training in business and cognitive institutions relating to accumulated business experience, probably because they offer a guide to valid behaviour. Thus, these two institutional dimensions seem to complement each other to offer the individual the basic knowledge to become an entrepreneur, which is relevant when such a decision is unintentional and unplanned. Perceiving cultural values that lend dignity to entrepreneurship does not affect the necessity component for this group. Focusing on the non-entrepreneurs, we note that the regulative institutions that generate this component are the ones that provide legal incentives for entrepreneurship. As happens with the entrepreneurs, perceiving in the area accumulated business experience that offers a model to imitate also has a positive effect on the necessity component for non-entrepreneurs. Finally, for this group, the existence of cultural values that lend dignity to entrepreneurship does represent a positive determinant factor. Thus, for non-entrepreneurs constructing the necessity component seems to require a greater perceived institutional support than constructing the opportunity component. These results for the non-entrepreneurs suggest that the opportunity component seems to derive more from the individual's entrepreneurial dream than from an analysis of their immediate environment. The fact that the opportunity component of motivation develops without such broad institutional support may explain why the entrepreneurial intentions based on opportunity among the non-entrepreneurs do not end up materialising in action in developing countries. This interpretation of the results is coherent with our findings for the entrepreneurs. Nevertheless, a necessity motivation based on normative institutions that legitimise entrepreneurship as a professional option, cognitive institutions concerning the existence of models to imitate that guide new entrepreneurs, and regulative institutions generating economic incentives for entrepreneurship will produce more solid entrepreneurial motivations that are more likely to lead to actual entrepreneurial behaviour in developing economies. This is because of the consistency between the institutional reality of the environment perceived by the individual and the necessity component of their entrepreneurial motivation that they construct.

We now look at the relative importance of each of the institutional dimensions in their capacity to stimulate a particular component of entrepreneurial motivation. Our results allow us to conclude that the regulative institutions are the least important among the entrepreneurs for all three motivational components, and also for the opportunity component among the non-entrepreneurs. The instability of the legislative body may undermine the capacity of the regulative institutions to encourage entrepreneurial motivation, as previous literature suggests (Puffer et al. 2010) and empirical works have found (Lim et al. 2016; Valdez \& Richardson 2013). This is because these institutions' influence is associated with the use of rational criteria in evaluating the environment, a question that our evidence shows only becomes critical for the necessity component among non-entrepreneurs. In the case of these individuals, their situation of extreme necessity may lead them to see a framework of regulative incentives as relevant for their entrepreneurial motivation, although this framework may only be operational in the short or medium term. Thus, as an addition to previous works' focus on entrepreneurial activity (e.g. Lim et al. 2016; Valdez \& Richardson 2013), our study identified the fact that the regulative aspect of institutions matters for increasing the necessity component of the motivation of non-entrepreneurs in developing economies. In addition, and again in line with our results, previous authors have stressed that because of the high uncertainty associated with these unstable regulative environments (Meyer \& Nguyen 2005), the normative and cognitive institutions determine the emergence of entrepreneurial motivation to a greater extent than the regulative ones (Lim et al. 2016; Puffer et al. 2010).

Finally, we identify the cognitive institutions as having the greatest effect on the development of all three components of entrepreneurial motivation for the group of entrepreneurs, reflecting the importance of knowledge for progress in developing economies, which is in line with Simón-Moya 
et al.'s (2014) generic results. Again, we find an important difference with respect to the non-entrepreneurs because the cognitive institutions are always the least important for developing their entrepreneurial motivation. In our opinion, it is because these individuals are still not close to taking entrepreneurial action which explains why they focus more intensely on factors unrelated, at least directly, to the resources they need to start a firm and run it successfully.

\section{Conclusion}

This research offers interesting theoretical and methodological insights, as well as practical implications for improving the planning of growth in developing economies since we identify the institutional factors that generate each component of entrepreneurial motivation.

\section{Theoretical contributions}

Firstly, and this represents a novelty in the literature on entrepreneurship in developing countries, the current work identifies institutional factors that influence the gestation of the individual's desire to be an entrepreneur and those that lead them to actually start their own firm and become an entrepreneur. This distinction is very important for these economies because the different components of entrepreneurial motivation do not generate an equal proportion of productive entrepreneurship (Acs et al. 2008; Valliere \& Peterson 2009). In this respect, whereas three components of entrepreneurial motivation are identified for entrepreneurs, that is, opportunity, necessity and social components, only the first two are identified for nonentrepreneurs. Secondly, our work finds that the probability of being an entrepreneur with opportunity, social and necessity components of entrepreneurial motivation, will depend on individuals' perception of the institutional environment. Thirdly, education is an important factor favouring the opportunity component among individuals who eventually become entrepreneurs, the educated population being in the best position to achieve it; in addition, the cognitive institutions concerning the existence of business experience accessible to new entrepreneurs are most responsible for the emergence of the social and necessity components of entrepreneurial motivation. Referring to normative institutions, they are the most relevant for stimulating the opportunity component of entrepreneurial motivation, mainly among non-entrepreneurs. In contrast, the incentives designed to encourage people to create firms do not achieve the expected results. This is because these incentives apparently have no influence on any of the three components studied here for the group of entrepreneurs, nor on the opportunity component among the non-entrepreneurs. This may be because there is little trust that this regulation will remain stable over time.

\section{Methodological contributions}

Unlike previous studies that analyse the effect of the institutional environment on entrepreneurship from a macro-level of analysis, and so compare countries on the basis of data available in international data sets, the current work is based on neo-institutionalism and uses a micro-level perspective to analyse how the individual's perception of the institutional environment in a given developing country affects their entrepreneurial motivation. As the institutional dimensions scale, built to measure the perception of regulative, normative and cognitive factors, allows us to identify differences in the perception of institutions in a developing economy, as well as their effects on the entrepreneurial motivation in both of the subsamples, 'entrepreneurs' and 'non-entrepreneurs', the research instrument can be considered as a methodological contribution. The instrument also shows reliability, as well as content validity and construct validity in both subsamples. So, further authors may find it useful for studying institutional factors from the most recent versions of new institutionalism.

\section{Practical implications}

As there exist differences in the impact of the dimensions of institutions, as perceived by an individual, on the components of their entrepreneurial motivation, a first and practical implication of this work is that policies aimed at boosting a given component of entrepreneurial motivation (e.g. opportunity) should not be similar to those aiming at stimulating the other components (e.g. social, necessity). Secondly, as institutional factors exert a different influence on the entrepreneurial motivation of non-entrepreneurs and entrepreneurs, such policies should likely be based on a segmentation of the target audience, for example distinguishing between young people whose motivation to become entrepreneurs in the future may be stimulated, and adults already in a position to actually start their own business. It seems necessary in order for the programmes that are designed, to reach the objectives for which they are conceived. Thirdly, because components of entrepreneurial motivation will depend on the individual's perception of the institutional environment, government policies could be targeted not only at enhancing those institutional factors that positively affect components of entrepreneurial motivation that are of interest, but also at modifying people's perceptions of such regulative, normative and cognitive institutions, as Zwan et al. (2016) also suggest. Fourthly, and from an educative perspective, since aspects of cognitive institutions related to education are important factors favouring the opportunity component among individuals who eventually become entrepreneurs, authorities should make greater efforts to reconcile the regulative and cognitive institutions that favour productive entrepreneurship by designing laws that guarantee an officially recognised higher-level training, as well as the population's access to and success in the educational system in all its different stages. In addition, and because normative institutions are of relevance to non-entrepreneurs, especially for increasing the opportunity component of motivation, training efforts could also be focused on socialising people, especially the younger generations, in existing values that legitimise entrepreneurial activities in the country. Also, training of young people could focus on shaping those 
normative beliefs that expectedly will increase entrepreneurial motivation, for example by carrying out activities similar to the ones suggested by Valdez and Richardson (2013): earlier exposure to entrepreneurial experiences and concepts, gamification of entrepreneurship using software of simulation, creation of entrepreneurship contests and competitions, awards to better projects, inclusion of entrepreneurship in elementary to post-secondary curricula, etc.

\section{Limitations and future research}

Finally, although the use of a single country is suitable for allowing researchers to analyse the differences between individuals' perceptions of institutions, the doubt remains whether the conclusions we reach are relevant beyond the particular geographic context analysed or not. Dunkelberg et al. (2013) warns that the psychology of entrepreneurship is likely to vary in different societies, both in terms of the entrepreneurial motivations and of the effect of these motivations on the entrepreneurs' behaviour. In addition, as we collected data from a survey focused on participant's opinions, our results may be subject to self-report biases. For example, individuals may report high in components of entrepreneurial motivations that are socially desired (e.g. entrepreneurs could say they started a business because they wanted to make a social contribution instead of confessing that they had no other option or were motivated purely by the prospect of financial gain (Zwan et al. 2016). Furthermore, our work focuses on understanding how the individual's perception of institutions affects the construction of the different components of their entrepreneurial motivation, so we ignore other relevant questions for understanding this phenomenon, such as the individual's psychological traits and other personality characteristics, such as their entrepreneurial alertness, propensity to assume risks, and so on. Therefore, the literature would benefit from future research aiming to address this limitation. In addition, because according to some authors institutional dimensions are interlinked (Szyliowicz \& Galvin 2010), researchers could empirically study how they interact to generate each component of entrepreneurial motivation.

\section{Acknowledgements}

Financial support from Spain's Economy, Industry and Competitiveness National Department (Project: ECO201680518-R) is gratefully acknowledged.

\section{Competing interests}

We declare that we have no significant competing financial, professional, or personal interests that might have influenced the performance or presentation of the work described in this manuscript.

\section{Authors contributions}

A.M.G-C. conceived and designed the research questions or hypotheses, performed the literature research on components of entrepreneurial motivation and wrote discussion and conclusions. M.G.G-S. performed the literature research on methodologies to study institutions, the scales of measurement, checked the reliability and validity of measurements, analysed the data and wrote results. J.D-F. performed the literature research on the institutional environment and the individual's institutional perceptions, wrote the Cape Verde background, and managed all the tasks related to the fieldwork.

\section{References}

Acs, Z.J., Desai, S. \& Hessels, J., 2008, 'Entrepreneurship, economic development and institutions', Small Business Economics 31, 219-234. https://doi.org/10.1007/ s11187-008-9135-9

Azmat, F., 2013, 'Sustainable development in developing countries: The role of social entrepreneurs', International Journal of Public Administration 36(5), 293-304. https://doi.org/10.1080/01900692.2012.756891

Battilana, J., Leca, B. \& Boxenbaum, E., 2009, 'How actors change institutions: Towards a theory of institutional entrepreneurship', The Academy of Management Annals 3(1), 65-107. https://doi.org/10.5465/19416520903053598

Birley, S. \& Westhead, P., 1994, 'A taxonomy of business start-up reasons and their impact on firm growth and size', Journal of Business Venturing 9(1), 7-31. https:// doi.org/10.1016/0883-9026(94)90024-8

Bjørnskov, C. \& Foss, N.J., 2016, 'Institutions, entrepreneurship, and economic growth: What do we know and what do we still need to know?', The Academy of Management Perspectives 30(3), 292-315. https://doi.org/10.5465/amp.2015.0135

Block, J.H. \& Sandner, P., 2009, 'Necessity and opportunity entrepreneurs and their duration in self-employment: Evidence from German micro data', Journal of Industry, Competition and Trade 9, 117-137. https://doi.org/10.1007/s10842007-0029-3

Block, J.H. \& Wagner, M., 2010, 'Necessity and opportunity entrepreneurs in Germany: Characteristics and earnings differentials', Schmalenbach Business Review 62(2), 154-174. https://doi.org/10.1007/BF03396803

Busenitz, L.W., Gomez, C. \& Spencer, J.W., 2000, 'Country institutional profiles: Unlocking entrepreneurial phenomena', Academy of Management Journal 43(5), 994-1003.

Cassar, G., 2007, 'Money, money, money? A longitudinal investigation of entrepreneur career reasons, growth preferences and achieved growth', Entrepreneurship and Regional Development 19(1), 89-107. https://doi.org/10.1080/08985620601002246

Carsrud, A. \& Brännback, M., 2011, 'Entrepreneurial motivations: What do we stil need to know?', Journal of Small Business Management 49(1), 9-26. https://doi. org/10.1111/j.1540-627X.2010.00312.X

Dunkelberg, W., Moore, C., Scott, J. \& Stull, W., 2013, 'Do entrepreneurial goals matter? Resource allocation in new owner-managed firms', Journal of Business Venturing 28, 225-240. https://doi.org/10.1016/j.jbusvent.2012.07.004

Dunning, J.H. \& Lundan, S.M., 2008, 'Institutions and the OLI paradigm of the multinational enterprise', Asia Pacific Journal of Management 25, 573-593. https://doi.org/10.1007/s10490-007-9074-z

Fossen F.M. \& Büttner, T.J.M., 2013, 'The returns to education for opportunity entrepreneurs, necessity entrepreneurs, and paid employees', Economics of Education Review 37, 66-84. https://doi.org/10.1016/j.econedurev.2013.08.005

García-Cabrera, A.M., García-Soto, M.G. \& Durán-Herrera, J.J., 2016, 'Opportunity motivation and SME internationalisation in emerging countries: Evidence from entrepreneurs' perception of institutions', International Entrepreneurship and Management Journal 12(3), 879-910. https://doi.org/10.1007/s11365-016-0386-7

Ghalwash, S., Tolba, A. \& Ismail, A., 2017, 'What motivates social entrepreneurs to start social ventures? An exploratory study in the context of a developing economy', Social Enterprise Journal 13(3), 268-298. https://doi.org/10.1108/SEJ05-2016-0014

Greenwood, R. \& Hinings, C.R., 1996, 'Understanding radical organizational change: Bringing together the old and the new institutionalism', Academy of Management Review 21, 1022-1054. https://doi.org/10.5465/amr.1996.9704071862

Hechavarria, M. \& Reynolds, P., 2009, 'Cultural norms \& business start-up: The impact of national values on opportunity and necessity entrepreneurs', International Entrepreneurship and Management Journal 5, 417-437. https://doi.org/10.1007/ s11365-009-0115-6

Herrington, M., Kew, J. \& Kew, P., 2010, Global entrepreneurship monitor, UCT Centre for Innovation and Entrepreneurship, Cape Town.

Hoffman, A.J. \& Ventresca, M.J., 2002, Organizations, policy and the Natural Environment: Institutional and strategic perspectives, Stanford University Press, Stanford, CA.

Huang, Y. \& Sternquist, B., 2007, 'Retailer's foreign market entry decisions: An institutional perspective', International Business Review 16, 613-629. https://doi. org/10.1016/j.ibusrev.2007.06.005

INE (Instituto Nacional de Estatística de Cape Verde), 2017, Población y Condiciones de Vida en Cabo Verde, viewed from http://www.ine.cv

Jayawarna, D., Rouse, J. \& Kitching, J., 2013, 'Entrepreneur motivations and life course', International Small Business Journal 31(1), 34-56. https://doi.org/ $10.1177 / 0266242611401444$ 
Kautonen, T., Gelderen, M. \& Fink, M., 2015, 'Robustness of the theory of planned behavior in predicting entrepreneurial intentions and actions', Entrepreneurship Theory and Practice 39(3), 655-674. https://doi.org/10.1111/etap.12056

Krueger, N.F., Reilly, M.D. \& Carsrud, A.L., 2000, 'Competing models of entrepreneurial intentions', Journal of Business Venturing 15(5-6), 411-432. https://doi.org/ 10.1016/S0883-9026(98)00033-0

Lim, D.S., Oh, C.H. \& De Clercq, D., 2016, 'Engagement in entrepreneurship in emerging economies: Interactive effects of individual-level factors and institutional conditions', International Business Review 25(4), 933-945. https:// doi.org/10.1016/j.ibusrev.2015.12.001

Lu, J.W., 2002, 'Intra and inter-organizational imitative behaviour: Institutional influences on Japanese firms' entry mode choice', Journal of International Business Studies 33(1), 19-37. https://doi.org/10.1057/palgrave.jibs.8491003

Mair, J. \& Martí, I., 2006, 'Social entrepreneurship research: A source of explanation, prediction, and delight', Journal of World Business 41, 36-44. https://doi. org/10.1016/j.jwb.2005.09.002

Manolova, T.S., Eunni, R.V. \& Gyoshev, B.S., 2008, 'Institutional environments for entrepreneurship: Evidence from emerging economies in Eastern Europe' Entrepreneurship Theory \& Practice 31(1), 203-218. https://doi.org/10.1111/ j.1540-6520.2007.00222.x

Mahto, R.V. \& McDowell, W.C., 2018, 'Entrepreneurial motivation: A non-entrepreneur's journey to become an entrepreneur', International Entrepreneurship and Management Journal 14(1), 1-14. https://doi.org/10.1007/s11365-018-0513-8

Meyer, K.E., Estrin, S., Bhaumik, S.K. \& Peng, M.V., 2009, 'Institutions, resources, and entry strategies in emerging economies', Strategic Management Journal 30 61-80. https://doi.org/10.1002/smj.720

Meyer, K. \& Nguyen, V.C., 2005, 'Foreign investment strategies and sub-national institutions in emerging markets: Evidence from Vietnam', Journal of Managemen Studies 42, 22-80. https://doi.org/10.1111/j.1467-6486.2005.00489.x

North, D.C., 1990, Institutions, institutional change and economic performance, Cambridge University Press, Cambridge.

Podsakoff, P.M. \& Organ, D.W., 1986. 'Self-reports in organizational research: Problems and prospects', Journal of Management 12(4), 531-544. https://doi.org/ $10.1177 / 014920638601200408$

Puffer, S.M., McCarthy, D.J. \& Boisot, M., 2010, 'Entrepreneurship in Russia and China: The impact of formal institutional voids', Entrepreneurship Theory \& Practice 34(3), 441-467. https://doi.org/10.1111/j.1540-6520.2009.00353.x

Renko, M., 2013, 'Early challenges of nascent social entrepreneurs', Entrepreneurship Theory \& Practice 37(5), 1045-1069. https://doi.org/10.1111/j.1540-6520.2012. 00522.x

Scott, W.R., 1995, Institutions and organizations, Sage, Thousand Oaks, CA.
Shane, S., Locke, E.A. \& Collins, C.J., 2003, 'Entrepreneurial motivation', Human Resource Management Review 13(2), 257-279. https://doi.org/10.1016/S10534822(03)00017-2

Simón-Moya, V., Revuelto-Taboada, L. \& Fernández-Guerrero, R., 2014, 'Institutional and economic drivers of entrepreneurship: An international perspective', Journal of Business Research 67(5), 715-721. https://doi.org/10.1016/j.jbusres.2013.11.033

Stenholm, P., Acs, Z.J. \& Wuebker, R., 2013, 'Exploring country-level institutional arrangements on the rate and type of entrepreneurial activity', Journal of Business Venturing 28, 176-193. https://doi.org/10.1016/j.jbusvent.2011.11.002

Sullivan, A. \& Sheffrin, S.M., 2003, Economics: Principles in action, Pearson Prentice Hall, Upper Saddle River, NJ.

Szyliowicz, D. \& Galvin, T., 2010, 'Applying broader strokes: Extending institutional perspectives and agendas for international entrepreneurship research', International Business Review 19, 317-332. https://doi.org/10.1016/j.ibusrev.2010.01.002

Tominc, P. \& Rebernik, M., 2007, 'Growth aspirations and cultural support for entrepreneurship. A comparison of post-socialist countries', Small Business Economics 28, 239-255. https://doi.org/10.1007/s11187-006-9018-x

UCRE (Unidade de Coordenação da Reforma do Estado) \& ONUDI (Organização das Nações Unidas para o Desenvolvimento Industrial), 2011, Melhoria do Ambiente de Negócios em Cabo Verde, viewed 16 June 2012, from www.reformadoestado.gov.cv

Urban, B., 2013, 'Influence of the institutional environment on entrepreneurial intentions in an emerging economy', The International Journal of Entrepreneurship and Innovation 14(3), 179-191. https://doi.org/10.5367/ijei.2013.0122

United Nations, 2014, Country classification, viewed 20 April 2018, http://www. un.org/en/development/desa/policy/wesp/wesp_current/2014wesp_country classification.pdf

Valdez, M.E. \& Richardson, J., 2013, 'Institutional determinants of macro-leve entrepreneurship', Entrepreneurship Theory and Practice 37(5), 1149-1175. https://doi.org/10.1111/etap.12000

Valliere, D. \& Peterson, R., 2009, 'Entrepreneurship and economic growth: Evidence from emerging and developed countries', Entrepreneurship and Regiona Development 21(5), 480-559. https://doi.org/10.1080/08985620802332723

Williams, C., 2009, 'The motives of off-the-books entrepreneurs: Necessity- or opportunity-driven?', International Entrepreneurship and Management Journal 5 , opportunity-driven?', International Entrepreneurship and

Williams, C.C. \& Gurtoo, A., 2017, 'The institutional environment of entrepreneurship in developing countries: An introductory overview', in C.C. Willians \& A. Gurtoo (eds.), Routledge handbook of entrepreneurship in developing economies, (eds.), Routledge handbook of
pp. 13-16, Routledge, New York.

Zwan, P. Van der, Thurik, R., Verheul, I. \& Hessels, J., 2016, 'Factors influencing the entrepreneurial engagement or opportunity and necessity entrepreneurs', Eurasian Business Review 6, 273-295. https://doi.org/10.1007/s40821-016-0065-1 


\section{Appendix 1}

TABLE 1-A1: Entrepreneurial Motivation Scale. Configuration matrix from SPSS Pc 17.0: Non-entrepreneurs and entrepreneurs subsamples.

\begin{tabular}{|c|c|c|c|c|c|}
\hline \multirow[t]{2}{*}{ Factors (synthetic indicators) } & \multirow[t]{2}{*}{ Items: In my desire to have a firm, I was influenced by } & \multicolumn{2}{|c|}{ Non-entrepreneurs } & \multicolumn{2}{|c|}{ Entrepreneurs } \\
\hline & & CL. & Comm. & CL. & Comm. \\
\hline \multirow[t]{5}{*}{ Factor 1: Opportunity } & ... the fact that I saw that the sector was profitable for a business & 0.688 & 0.519 & 0.814 & 0.726 \\
\hline & ... the fact that I possess the right professional qualities to create my own firm & 0.748 & 0.586 & 0.790 & 0.641 \\
\hline & ... the fact that I wanted to run my own business & 0.785 & 0.620 & 0.757 & 0.716 \\
\hline & $\%$ of variance explained by factor & \multicolumn{2}{|c|}{25.441} & \multicolumn{2}{|c|}{23.219} \\
\hline & Alpha & \multicolumn{2}{|c|}{0.607} & \multicolumn{2}{|c|}{0.751} \\
\hline \multirow[t]{7}{*}{ Factor 2: Necessity } & ... the sector I was working in was in decline & 0.864 & 0.746 & 0.912 & 0.854 \\
\hline & ... I earned very little in my previous job & 0.857 & 0.734 & 0.854 & 0.747 \\
\hline & ... I wanted to find jobs for my children & - & - & 0.516 & 0.582 \\
\hline & ... I wanted to improve my working conditions & 0.690 & 0.604 & - & - \\
\hline & ... I was unemployed and I needed a job & 0.678 & 0.463 & - & - \\
\hline & $\%$ of variance explained by factor & \multicolumn{2}{|c|}{35.579} & \multicolumn{2}{|c|}{21.437} \\
\hline & Alpha & \multicolumn{2}{|c|}{0.782} & \multicolumn{2}{|c|}{0.706} \\
\hline \multirow[t]{4}{*}{ Factor 3: Social } & ... the need to create more jobs in my town & - & - & 0.849 & 0.733 \\
\hline & ... the wish to have a job in which I could be in contact with other people & - & - & 0.746 & 0.631 \\
\hline & $\%$ of variance explained by factor & \multicolumn{2}{|c|}{-} & \multicolumn{2}{|c|}{25.867} \\
\hline & Alpha & \multicolumn{2}{|c|}{-} & \multicolumn{2}{|c|}{0.780} \\
\hline Cumulative variance explained (\%) & - & \multicolumn{2}{|c|}{61.019} & \multicolumn{2}{|c|}{70.523} \\
\hline KMO & - & \multicolumn{2}{|c|}{0.702} & \multicolumn{2}{|c|}{0.710} \\
\hline Bartlett Sphericity & - & \multicolumn{2}{|c|}{214.897} & \multicolumn{2}{|c|}{290.144} \\
\hline$p$ & - & \multicolumn{2}{|c|}{0.000} & \multicolumn{2}{|c|}{0.000} \\
\hline Alpha & - & \multicolumn{2}{|c|}{0.686} & \multicolumn{2}{|c|}{0.774} \\
\hline$N$ & - & \multicolumn{2}{|c|}{117} & \multicolumn{2}{|c|}{93} \\
\hline
\end{tabular}

$\mathrm{CL}$, component loadings; Comm, communalities. 


\section{Appendix 2}

TABLE 1-A2: Institutional dimensions scale. Configuration matrix from SPSS Pc 17.0: Non-entrepreneurs and entrepreneurs subsamples.

\begin{tabular}{|c|c|c|c|c|c|}
\hline \multirow{2}{*}{$\begin{array}{l}\text { Factors } \\
\text { (synthetic indicators) }\end{array}$} & \multirow[t]{2}{*}{ Items: In my town ... } & \multicolumn{2}{|c|}{ Non-entrepreneurs } & \multicolumn{2}{|c|}{ Entrepreneurs } \\
\hline & & CL. & Comm. & CL. & Comm. \\
\hline \multirow{8}{*}{$\begin{array}{l}\text { Normative factor } \\
\text { (F1.Nor): } \\
\text { Entrepreneur's image } \\
\text { and social status }\end{array}$} & ... successful entrepreneurs enjoy high status and respect in society & - & - & 0.771 & 0.744 \\
\hline & ... creating new firms is considered a morally good way to make money & 0.773 & 0.631 & 0.705 & 0.746 \\
\hline & ... the majority of people think that entrepreneurs are competent and self-sufficient & 0.697 & 0.605 & 0.685 & 0.678 \\
\hline & ... becoming an entrepreneur is considered a desirable professional option & 0.751 & 0.607 & 0.654 & 0.691 \\
\hline & ... business skills, creativity and innovative thinking are highly valued & - & - & 0.588 & 0.570 \\
\hline & ... people who start new businesses are portrayed as successful in the media & 0.702 & 0.545 & - & - \\
\hline & $\%$ of variance explained by factor & \multicolumn{2}{|c|}{10.122} & \multicolumn{2}{|c|}{12.791} \\
\hline & Alpha & \multicolumn{2}{|c|}{0.730} & \multicolumn{2}{|c|}{0.778} \\
\hline \multirow{6}{*}{$\begin{array}{l}\text { Cognitive factor } \\
\text { (F1.Cog): Qualified } \\
\text { population available }\end{array}$} & ... there are people experienced in management & 0.839 & 0.768 & 0.816 & 0.813 \\
\hline & ... there is a workforce with university education & 0.696 & 0.622 & 0.775 & 0.723 \\
\hline & ... there is a workforce experienced in services and customer services & 0.761 & 0.641 & 0.770 & 0.681 \\
\hline & ... there is a workforce with knowledge of foreign languages & 0.643 & 0.582 & 0.584 & 0.678 \\
\hline & ... many people know customers' demands in terms of quality & 0.673 & 0.593 & - & - \\
\hline & Alpha & \multicolumn{2}{|c|}{0.815} & \multicolumn{2}{|c|}{0.813} \\
\hline \multirow{6}{*}{$\begin{array}{l}\text { Cognitive } \\
\text { factor (F2.Cog): } \\
\text { Local business } \\
\text { experience }\end{array}$} & ... there are many people experienced in creating new firms & 0.829 & 0.802 & 0.781 & 0.761 \\
\hline & ... many people know how to respond to good opportunities by creating new firms & - & - & 0.750 & 0.667 \\
\hline & ... almost everybody knows somebody who has recently set up a new firm & 0.850 & 0.847 & 0.630 & 0.672 \\
\hline & ... many people are able to organise the resources necessary to create a new firm & - & - & 0.558 & 0.605 \\
\hline & $\%$ of variance explained by factor & \multicolumn{2}{|c|}{7.785} & \multicolumn{2}{|c|}{11.169} \\
\hline & Alpha & \multicolumn{2}{|c|}{0.839} & \multicolumn{2}{|c|}{0.762} \\
\hline Cognitive & ... it is common to imitate successful foreign firms by creating similar firms & 0.857 & 0.768 & - & - \\
\hline $\begin{array}{l}\text { Tactor (F3. Cog): } \\
\text { Mimetic pressure }\end{array}$ & ... it is common to imitate successful local firms by creating similar firms & 0.780 & 0.710 & - & - \\
\hline & $\%$ of variance explained by factor & & & & \\
\hline & Alpha & & & & \\
\hline Regulative & ... the laws are applied to new firms predictably and coherently & 0.728 & 0.592 & 0.749 & 0.703 \\
\hline Legal incentive for & ... there are laws and regulations relating to new firm creation & - & - & 0.731 & 0.695 \\
\hline entrepreneurship & ... the regulations concerning new firms and growing firms are adequate and effective & 0.671 & 0.699 & 0.616 & 0.650 \\
\hline & $\%$ of variance explained by factor & & & & \\
\hline & Alpha & & & & \\
\hline Regulative & ... there is a good supply of professional training providing workers ready to hire & 0.778 & 0.689 & 0.750 & 0.668 \\
\hline Continuing training & ... there are continuous training courses for improving employees' knowledge and skills & 0.745 & 0.634 & 0.748 & 0.680 \\
\hline opportunities & ... sufficient training is offered to individuals who want to create a new firm & 0.740 & 0.656 & - & - \\
\hline & $\%$ of variance explained by factor & & & & \\
\hline & Alpha & & & & \\
\hline Regulative & ... the flexibility of the collective agreements favours the creation of new firms & 0.763 & 0.666 & 0.912 & 0.873 \\
\hline Flexible labour & ... the labour flexibility favours business & 0.848 & 0.776 & 0.895 & 0.830 \\
\hline legislation & ... the speed of the justice favours business & 0.678 & 0.563 & - & - \\
\hline & $\%$ of variance explained by factor & & & & \\
\hline & Alpha & & & & \\
\hline $\begin{array}{l}\text { Regulative } \\
\text { factor (F4.Reg): }\end{array}$ & $\begin{array}{l}\ldots \text { the administration carries out regular controls on the quality of the products } \\
\text { and services on offer }\end{array}$ & - & - & 0.806 & 0.800 \\
\hline of quality & ... there are regulations to ensure the quality of the products and services on offer & - & - & 0.756 & 0.791 \\
\hline & $\%$ of variance explained by factor & & & & \\
\hline & Alpha & & & & \\
\hline $\begin{array}{l}\text { Cumulative variance } \\
\text { explained }(\%)\end{array}$ & - & & & & \\
\hline KMO & - & & & & \\
\hline Bartlett Sphericity & - & & & & \\
\hline$p$ & - & & & & \\
\hline Alpha & - & & & & \\
\hline$N$ & - & & & & \\
\hline
\end{tabular}

$\mathrm{CL}$, component loadings; Comm, communalities. 